\title{
TISSUE CULTURE OF Cecropia glaziovii SNETH (URTICACEAE): VEGETATIVE MICROPROPAGATION AND PLANT REGENERATION FROM CALLUS
}

\author{
Cultura de tecidos de Cecropia glaziovii Sneth (Urticaceae): micropropagação \\ vegetativa e regeneração de plantas via calos
}

\begin{abstract}
Marcos Nopper Alves ${ }^{1}$
ABSTRACT

Cecropia glaziovii is a tree with used in Brazilian popular medicine. Methods allowing the clonal propagation of this species are of great interest for superior genotype multiplication and perpetuation. For this reason, we examined the effect of different culture media and different types of explants on adventitious shoot regeneration from callus and buds of $C$. glaziovii. Leaves, petioles and stipules obtained from aseptically grown seedlings or from pre-sterilized plants were used to initiate cultures. Adventitious shoot regeneration was achieved when apical and axillary buds were inoculated on gelled Murashige \& Skoog (MS) medium supplemented with 6benzylaminopurine alone (BAP) $\left(1.0,5.0\right.$ or $\left.10.0 \mathrm{mg} \mathrm{L}^{-1}\right)$ or combined with $\alpha$-naphthalene acetic acid (NAA) $\left(1.0\right.$ or $\left.2.0 \mathrm{mg} \mathrm{L}^{-1}\right)$, after 40 days of culture. Best callus production was obtained after 30 days of petioles' culture on gelled MS medium with 2,4 dichlorophenoxyacetic acid (2,4-D) $\left(5.0 \mathrm{mg} \mathrm{L}^{-1}\right)$ combined with BAP $\left(1.0 \mathrm{mg} \mathrm{L}^{-1}\right)$. Successful shoot regeneration from callus was achieved when MS medium supplemented with zeatin (ZEA) $\left(0.1 \mathrm{mg} \mathrm{L}^{-1}\right)$ alone or combined with 2,4-D (1.0 or $\left.5.0 \mathrm{mg} \mathrm{L}^{-1}\right)$ was inoculated with friable callus obtained from petioles. All shoots were rooted by inoculation on MS medium supplemented with indole-3-acetic acid (IAA) (1.0 $\left.\mathrm{mg} \mathrm{L}^{-1}\right)$. Rooted plants transferred to potting soil were successfully established. All in vitro regenerated plantlets showed to be normal, without morphological variations, being also identical to the source plant. Our study has shown that $C$. glaziovii can be propagated by tissue culture methods, allowing large scale multiplication of superior plants for pharmacological purposes.
\end{abstract}

Index terms: Medicinal plant, clonal propagation, adventitious buds, growth regulators, callogenesis.

\section{RESUMO}

Cecropia glaziovii é uma planta lenhosa, popularmente usada no Brasil como medicinal. Métodos que visem a sua propagação clonal podem ser de grande utilidade na preservação de seus genótipos de elite. Foram examinados efeitos de diferentes reguladores de crescimento e explantes na formação de brotações múltiplas a partir de calos e a partir de brotos apicais. Folhas, pecíolos e estípulas obtidas de plântulas assépticas e da esterilização de sementes ou através da esterilização direta dos explantes foram utilizados para iniciar os cultivos. Brotações múltiplas foram obtidas quando brotos apicais ou axilares foram inoculados em meios compostos de sais de Murashige \& Skoog (MS), suplementado com apenas 6-benzilaminopurine (BAP) (1,0, 5,0 ou 10,0 mg L $\left.\mathrm{m}^{-1}\right)$ ou combinado com ácido $\alpha$-naftaleno acético (ANA) $\left(1,0\right.$ ou $\left.2,0 \mathrm{mg} \mathrm{L}^{-1}\right)$, depois de 40 dias. A produção de calos foi obtida após 30 dias, quando pecíolos foram inoculados em meio MS acrescido de acido 2,4 diclorofenoxiacético (2,4-D) $\left(5,0 \mathrm{mg} \mathrm{L}^{-1}\right)$ combinado com BAP $\left(1,0 \mathrm{mg} \mathrm{L}^{-1}\right)$. A regeneração de brotos a partir de calos foi obtida quando meio MS acrescido de apenas zeatina (ZEA) $\left(0,1 \mathrm{mg} \mathrm{L}^{-1}\right)$ ou combinado com 2,4-D (1,0 ou 5,0 $\left.\mathrm{mg} \mathrm{L}^{-1}\right)$ foi inoculado com calos friáveis obtidos de pecíolos. As plântulas foram enraizadas em MS suplementado com ácido 3-indol acético (AIA) $\left(1.0 \mathrm{mg} \mathrm{L}^{-1}\right)$. A aclimatação das plântulas enraizadas foi estabelecida pela transferência para vasos contendo substrato orgânico e vermiculita sob umidade relativa 100\%. As plântulas regeneradas "in vitro" apresentaram aparência normal e idênticas à planta-mãe. Nosso estudo concluiu que genótipos de elite de C. glaziovii podem ser propagados em larga escala através de métodos "in vitro", proporcionando uma fonte confiável de matéria prima para estudos farmacológicos.

Termos para indexação: Plantas medicinais, propagação clonal, brotos adventícios, reguladores de crescimento, calogênesis.

(Received in june 17, 2009 and approved in february 2, 2010)

\section{INTRODUCTION}

Cecropia glaziovii Sneth. (Urticaceae) is a perennial tree used in the Brazilian popular medicine. It is native to the Atlantic Forest, widely occurring in the Serra do Mar, in the State of São Paulo (Corrêa, 1923; Lorenzi \& Matos, 2008). The popular use of this plant has received attention from the scientific community, leading to the study of its medicinal properties. The results obtained have attested to the use of the plant in the treatment of bronchitis, cough and cancer (Moreira, 1978; Hirschorn, 1981). Recent works also describe $C$. glaziovii as having hypotensive activities (Ninahuaman et al., 2007; Tanae et al., 2007; Lima-Landman, 2007; Souccar et al., 2008). Isovitexin, the only active component thus far identified in this species, is known to be diuretic and cardiotonic (Fonseca, 1935; Matos, 2000; Lorenzi, 2008), but there are reports indicating numerous substances

1Universidade Estadual de Campinas/UNICAMP - Cx. P. 6171 - 13083-970 - Campinas, SP - mnopper@cpqba.unicamp.br 
isolated from the Cecropia genus, involved in pharmacological actions already described (Lima-Landman et al., 2007).

This allogamous species presents a morphological variation within its natural populations, which can lead to differences in biomass yield and in the concentration of the active compound present in the leaves and stipules (Montanari Junior, 2002). As genetic, physiological and chemical variations are usually observed during the study of medicinal species, one observes that the biological activity of these plants is not always reproducible. Consequently, clones of plants that have high degrees of active principles would be of high value for chemical and pharmacological studies, as well for large-scale production.

Aiming to develop a protocol for in vitro culture of C. glaziovii, in this work we tested the effect of different growth regulators combinations and different explant types on the shoot regeneration derived from callus and from sterilized apical buds. Results shown that $C$. glaziovii can be clonally propagated, allowing large-scale multiplication.

\section{MATERIALS AND METHODS}

\section{Obtention of explants from seeds}

Seeds were collected in natural populations of $C$. glaziovii from the Serra do Mar, in the State of São Paulo, Brazil. They were washed in distilled water containing detergent, followed by three rinses with distilled water. Seeds were then surface-sterilized with $1.5 \%$ sodium hypoclorite for $20 \mathrm{~min}$, followed by five rinses in distilled autoclaved water. The seeds were transferred to culture flasks $(250 \mathrm{ml})$ containing $50 \mathrm{ml}$ of MS salts and vitamins (Murashige, 1962) with the addition of $100.0 \mathrm{mg} \mathrm{L}^{-1}$ of myoinositol. The $\mathrm{pH}$ was adjusted to 5.8 using $0.1 \mathrm{~N} \mathrm{NaOH}$ or $0.1 \mathrm{~N} \mathrm{HCl}$ before autoclaving. The medium was gelled with $0.8 \%$ (w/v) of agar (Difco Bacto agar). The culture flasks were autoclaved at $121^{\circ} \mathrm{C}$ and $104 \mathrm{kPa}$ for $30 \mathrm{~min}$. The cultures were incubated in a growth room with $16 \mathrm{~h}$ photoperiod with a combination of cool white fluorescent and incandescent lights $\left(40 \mu \mathrm{M} \mathrm{m}^{-2} \mathrm{~s}^{-1}\right)$ at $25 \pm 2^{\circ} \mathrm{C}$. Sections from leaf, petiole, stipules as well as apical buds were taken from 40-day-old aseptically grown seedlings for subsequent cultures.

\section{Obtention of explants from field plants}

Terminal stipules (Figure 1A) containing young leaves, petioles and apical buds were cut from one-yearold plants cultivated in the University of Campinas experimental field. They were surface-sterilized with $1.5 \%$ sodium hypochlorite for $10 \mathrm{~min}$, followed by five rinses in distilled autoclaved water. The internal leaves, petioles and apical buds (Figure 1B) are naturally aseptic and were used without previous sterilization.

\section{Callus induction}

With the purpose of callus induction, sections $\left(0.5 \mathrm{~mm}^{2}\right)$ of leaves, petioles and stipules were taken from sterilized field material and from aseptically-obtained plants, and placed on 90 $\mathrm{mm}$ diameter Petri dishes containing MS salts and vitamins (1962) with $100.0 \mathrm{mg} \mathrm{L}^{-1}$ of myo-inositol, and $30.0 \mathrm{~g} \mathrm{~L}^{-1}$ of sucrose, solidified with $8.0 \mathrm{~g} \mathrm{~L}^{-1}$ agar (Difco Bacto agar). The media were supplemented with different combinations of BAP (0.0 - 3.0 mg L-1) and 2,4-D (0.0 - $\left.10.0 \mathrm{mg} \mathrm{L}^{-1}\right)$, and the $\mathrm{pH}$ was adjusted to 5.8 prior to autoclaving at $121^{\circ} \mathrm{C}$ and $104 \mathrm{kPa}$ for $30 \mathrm{~min}$. The explants were cultivated at $25 \pm 2^{\circ} \mathrm{C}$ in the absence of light. The experiments of callus formation were set up in a completely randomized design and consisted of 5 replications of 30 explants per treatment. The treatments consist in different types of explants (leaves, petioles and stipules) inoculated in different combinations of growth regulators. Observations on the percentage of callus formation were made after 30 days of inoculation.

\section{Induction of adventitious buds from callus and apical buds}

Friable callus obtained after 30 days of culture of petioles in the dark were transferred to MS salts and vitamins containing $30 \mathrm{~g} \mathrm{~L}^{-1}$ of sucrose, $100,0 \mathrm{mg} \mathrm{L}^{-1}$ of myo-inositol and solidified with 7,0 $\mathrm{g} \mathrm{L}^{-1}$ agar supplemented with different concentrations of $\operatorname{BAP}(0.0,1.0,5.0$ and $\left.10.0 \mathrm{mg} \mathrm{L}^{-1}\right)$, ZEA $\left(0.0\right.$ and $\left.0,1 \mathrm{mg} \mathrm{L}^{-1}\right), 6$-(gamma,gammaDimethylallylamino)purine (2iP) $\left(0.0,0.1,0.5\right.$ and $\left.1.0 \mathrm{mg} \mathrm{L}^{-1}\right)$ and 2,4-D (0.0, 1.0, 3.0, 5.0 and $\left.10.0 \mathrm{mg} \mathrm{L}^{-1}\right)$ individually or in different combinations, in order to induce indirect organogenesis. The experiments of callus induction were completely randomized and consisted of five replicates of 10 calluses each, for each treatment of different combinations of growth regulators. Observations on the number of adventitious buds/callus obtained in each treatment were made after 30 days of culture.

In order to prepare the buds obtained from indirect organogenesis in callus or from apical buds from aseptically grown seedlings, assays aiming to promote elongation were made before the inoculation in the adventitious bud induction medium. Sterilized apical shoots were trimmed $(0.7-1.2 \mathrm{~cm})$ at the base and transferred to MS salts and vitamins containing $30 \mathrm{~g} \mathrm{~L}^{-1}$ of sucrose, $100,0 \mathrm{mg} \mathrm{L}^{-1}$ of myo-inositol and solidified with $7.0 \mathrm{~g} \mathrm{~L}^{-1}$ agar, where they were left for two weeks. Aiming adventitious bud induction, the elongated shoots were transferred to a secondary medium consisting of the MS medium prepared as described above, 
supplemented with BAP $\left(0.0,1.0,5.0\right.$ and $\left.10.0 \mathrm{mg} \mathrm{L}^{-1}\right), \mathrm{KIN}$ (0.0, 0.1, 1.0, 5.0, $\left.10.0 \mathrm{mg} \mathrm{L}^{-1}\right), 2 \mathrm{iP}\left(0.0,0.1,0.5\right.$ and $\left.1.0 \mathrm{mg} \mathrm{L}^{-1}\right)$, NAA $\left(0.0,1.0,2.0\right.$ and $\left.5.0 \mathrm{mg} \mathrm{L}^{-1}\right)$ and IAA $(0.0,0.5$ and $\left.1.0 \mathrm{mg} \mathrm{L}^{-1}\right)$ individually or in different combinations. The experiments of adventitious bud induction were completely randomized and consisted of five replicates of 15 calluses each, for each treatment of different combinations of growth regulators. Observations on the number of adventitious shoots/bud obtained in each treatment were made after 45 days of culture.

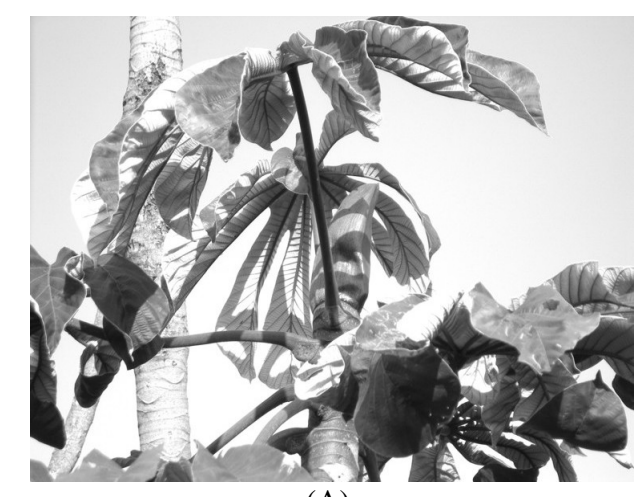

(A)

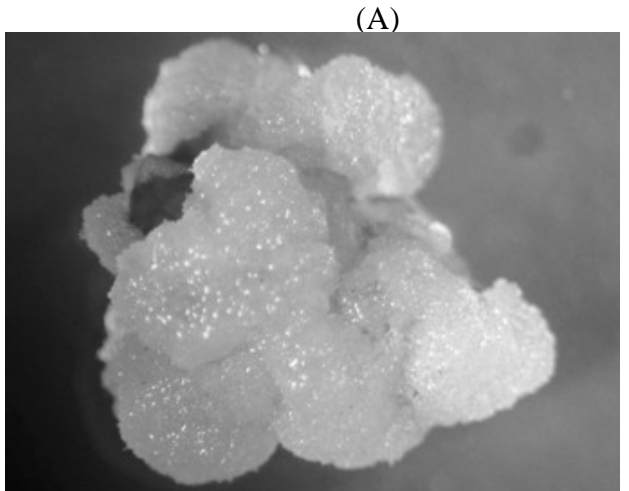

(C)

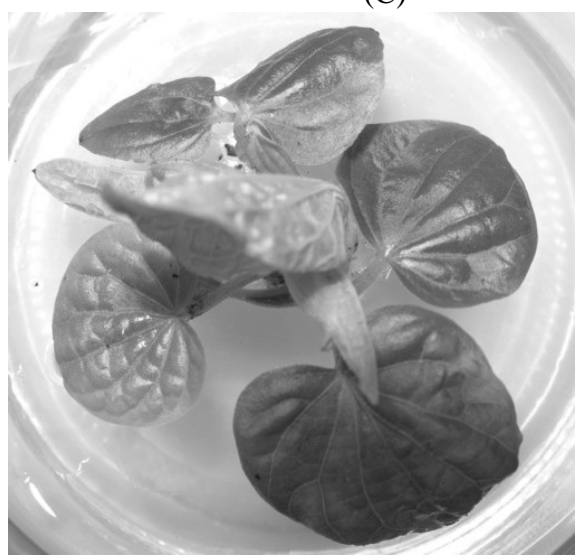

(E)

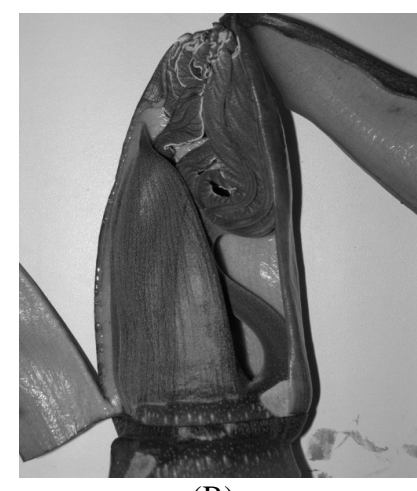

(B)

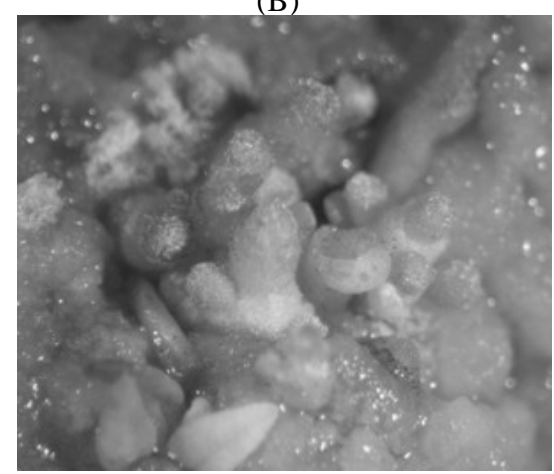

(D)

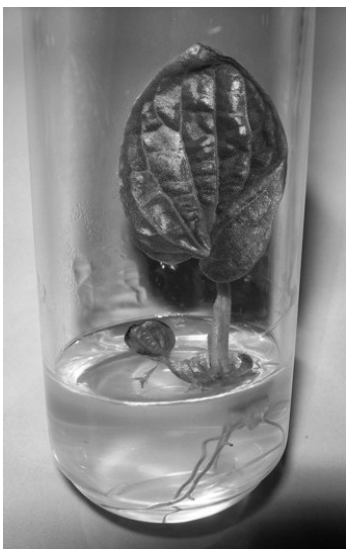

(F)

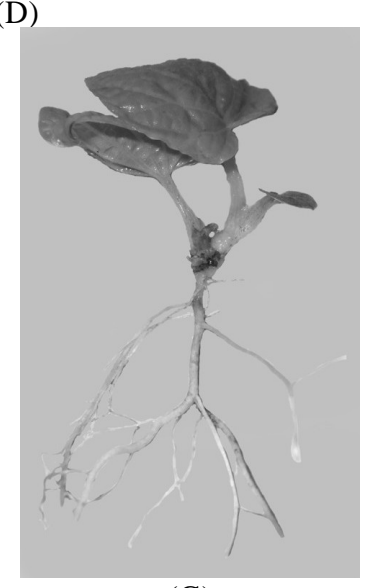

(G)

Figure 1 - (A-G) In vitro propagation of Cecropia glaziovii. (A) 12 months old plant in the field. Arrow indicates de stipulate. (B) Internal view of apical stipulate, showing aseptic new leaves and internal stipulate. (C) 30 day old friable callus derived from petioles. (D) Multiple bud formation developed from callus after 45 days on MS medium containing $0.1 \mathrm{mg} \mathrm{L}^{-1}$ of ZEA. (E) Shoots developed from adventitious buds after 40 days on MS containing BAP and NAA. (F) Elongated shoot after 30 days, transferred on rooting medium supplemented with $1.0 \mathrm{mg} \mathrm{L}^{-1}$ of IAA. (G) Rooted plant prepared for acclimatization. 
The media of all the experiments of adventitious shoot formation were dispensed in $250 \mathrm{ml}$ flasks sealed with plastic covers and had $\mathrm{pH}$ adjusted to 5.8 prior to autoclaving at $121^{\circ} \mathrm{C}$ and $104 \mathrm{kPa}$ for $30 \mathrm{~min}$. The cultures were incubated at $25 \pm 2^{\circ} \mathrm{C}$ under illumination of $40 \mu \mathrm{mol} \mathrm{m} \mathrm{m}^{-2} \mathrm{~s}^{-1}$ at a $16 \mathrm{~h}$ photoperiod using a combination of cool, white fluorescent and incandescent lights.

\section{Rooting and acclimatization}

For rooting induction, 8-9 weeks-old shoots (2.0-3.0 $\mathrm{cm}$ in length) obtained by vegetative multiplication or by callus differentiation were cultured on MS basal medium supplemented with $3 \%$ sucrose (w/v) and different concentrations of IBA $\left(0.0,0.1,2.0\right.$ and $\left.5.0 \mathrm{mg} \mathrm{L}^{-1}\right)$, IAA $(0.0$, $0.1,0.5$ and $\left.1.0 \mathrm{mg} \mathrm{L}^{-1}\right)$ and NAA $\left(0.0,0.1,0.5\right.$ and $\left.1.0 \mathrm{mg} \mathrm{L}^{-1}\right)$ individually. For each treatment, 5 replicates with 5 shoots each were cultured in $250 \mathrm{ml}$ flasks, in the conditions described above. The $\mathrm{pH}$ was adjusted to 5.8 prior to autoclaving at $121^{\circ} \mathrm{C}$ and $104 \mathrm{kPa}$ for $30 \mathrm{~min}$. Observations on the number and on the length of roots/shoot in each treatment were made after 30 days of culture. Rooted shoots were acclimatized in autoclaved vermiculite: organic substrate $(1: 1 \mathrm{v} / \mathrm{v})$ for 12 days under high humidity (90-100\%), making use of plastic bags for covering the plants. After this period, plants were transplanted to plastic pots containing a mixture of soil and vermiculite (3:1) under greenhouse conditions. After 20 days, the plants were transferred to the experimental field.

All the experiments were set up in a completely randomized design and the results were compared using a repeated measure - ANOVA, followed by a multiple comparison Tukey test (Zar, 1999).

\section{RESULTSAND DISCUSSION}

Callus induction, indirect organogenesis and vegetative multiplication

Petioles, leaves and stipules of C. glaziovii grown on MS medium containing different plant growth regulators, swelled and began to form callus after two weeks of culture. After 30 days of culture there were remarkable differences among callus derived from petioles, leaves and stipules in terms of texture, color and percentage of response (Table 1). The most effective treatments were those in which petioles were inoculated with 2,4-D in concentrations higher than $5.0 \mathrm{mg} \mathrm{L}^{-1}$ combined with BAP (1.0 and $\left.3.0 \mathrm{mg} \mathrm{L}^{-1}\right)$. A synergistic effect for callus formation was observed in combinations of the auxin 2,4-D with indole-3-butiric acid (IBA) at 1.0 and $3.0 \mathrm{mg} \mathrm{L}^{-1}$, corroborating previous results obtained in Digitalis obscura (Bermúdez et al., 1984). This type of combination seems to be interesting for the induction of

Table 1 - Effect of growth regulators on callus induction from different explants (petiole, leaves and stipulate) of Cecropia glaziovii after 30 days of culture.

\begin{tabular}{|c|c|c|c|c|}
\hline \multicolumn{2}{|c|}{ Growth regulators $\left(\mathrm{mg} \mathrm{L}^{-1}\right)$} & \multicolumn{3}{|c|}{ Callus induction (\%) } \\
\hline BAP & $2,4-\mathrm{D}$ & Petioles & Leaves & Stipulate \\
\hline 0.0 & 0.0 & 0.00 & 0.00 & 0.00 \\
\hline 0.1 & 0.0 & 0.00 & 0.00 & 0.00 \\
\hline 1.0 & 0.0 & 0.00 & 0.00 & 0.00 \\
\hline 3.0 & 0.0 & $42.6 \pm 2.52 \mathrm{Da}$ & $25.9 \pm 0.08 \mathrm{Db}$ & $22.2 \pm 0.55 \mathrm{~Eb}$ \\
\hline 0.0 & 1.0 & $60.4 \pm 1.20 \mathrm{Ca}$ & $42.6 \pm 0.19 \mathrm{Cb}$ & $28.7 \pm 2.11 \mathrm{Ec}$ \\
\hline 0.0 & 5.0 & $88.1 \pm 0.71 \mathrm{Ba}$ & $75.3 \pm 0.21 \mathrm{Bb}$ & $50.4 \pm 1.11 \mathrm{Bc}$ \\
\hline 0.0 & 10.0 & $75.8 \pm 0.84 \mathrm{Ba}$ & $40.2 \pm 1.11 \mathrm{Cb}$ & $32.2 \pm 3.06 \mathrm{Dc}$ \\
\hline 0.1 & 1.0 & $56.8 \pm 2.44 \mathrm{Ca}$ & $41.2 \pm 0.28 \mathrm{Cb}$ & $45.2 \pm 2.43 \mathrm{Cb}$ \\
\hline 1.0 & 1.0 & $63.5 \pm 1.22 \mathrm{Ca}$ & $49.5 \pm 0.36 \mathrm{Cb}$ & $43.3 \pm 0.21 \mathrm{Cb}$ \\
\hline 3.0 & 1.0 & $68.3 \pm 0.09 \mathrm{Ca}$ & $42.4 \pm 0.92 \mathrm{Cb}$ & $35.7 \pm 1.78 \mathrm{Dc}$ \\
\hline 1.0 & 5.0 & $100.00 \mathrm{Aa}$ & $79.00 \pm 0.92 \mathrm{Ab}$ & $65.4 \pm 1.88 \mathrm{Ab}$ \\
\hline 3.0 & 5.0 & $100.00 \mathrm{Aa}$ & $72.4 \pm 2.01 \mathrm{Bb}$ & $57.3 \pm 2.34 \mathrm{Ac}$ \\
\hline 1.0 & 10.0 & $85.2 \pm 1.71 \mathrm{Ba}$ & $70.3 \pm 2.98 \mathrm{Bb}$ & $62.9 \pm 2.11 \mathrm{Ac}$ \\
\hline 3.0 & 10.0 & $81.4 \pm 1.78 \mathrm{Ba}$ & $74.1 \pm 1.23 \mathrm{Bb}$ & $62.0 \pm 1.55 \mathrm{Ac}$ \\
\hline
\end{tabular}

Two-way ANOVA was performed between each growth regulator combinations. Different capital letters in the collum and small letters in the lines mean significant differences at 5\% (post hoc Tukey test). 
friable callus. Combination with 2,4-D $5.0 \mathrm{mg} \mathrm{L}^{-1}$ lead to $100 \%$ effectiveness (Table 1).

Despite the positive results presented in previous works (Laimer et al., 1988; Leblay et al., 1991), we observed that leaves were not very effective in callus induction, result that corroborate with those obtained by Lima (2008). Moreover, work of Castro et al. 2009, shows that leaves are the best explants for callus induction in Stryphnodendron adstringens. These works reported better results when calluses were induced in the absence of light, which was also observed here.

Stipules displayed the worst results of percentage of callus formation (between $22 \%$ and $65 \%$ ), even when inoculated in the best medium (which allowed $100 \%$ of induction from petioles). This seems to be related to the hard coriaceous tissue of the stipules, which are less effective in responding to growth regulator actions.

The calluses obtained from petiole explants were normally friable and exhibited a clear yellow color (Figure 1C). In the other hand, calluses from leaves and stipules explants were brown and hard. BAP alone only had effect in the concentration of $3.0 \mathrm{mg} \mathrm{L}^{-1}$, with $42 \%$ of callus formation. Results obtained for 2,4-D alone were: $60-75 \%$ of callus formation from petioles, $40-75 \%$ from leaves and $28-50 \%$ for stipules, which indicates that petioles are the best explants for this purpose.

All calluses used in the experiments of adventitious bud formation were from petioles. Adventitious bud formation begins within 15 days after callus transfer to bud induction medium. After 30 days, observations on bud regeneration frequency showed variation according to the explant type and medium composition. Data about the effect of growth regulator combinations on the number of buds obtained per callus are summarized in Table 2 .

The results showed that calluses derived from petioles grown in the presence of $0.1 \mathrm{mg} \mathrm{L}^{-1} \mathrm{ZEA}$ gave rise to the higher number of buds. Significant differences were observed after 45 days in the mean level of bud formation on responsive culture media, with the maximum of 6.53 buds per callus (Figure 1D). A combination of ZEA $0.1 \mathrm{mg} \mathrm{L}^{-1}$ and 2,4-D (1.0 and $\left.3.0 \mathrm{mg} \mathrm{L}^{-1}\right)$ also induced bud formation from calluses derived from petioles, but the bud number per callus was significantly lower (5.4 and 5.3 buds per callus, respectively). Burbulis et al. (2008) obtained the maximum response of bud induction in callus of Brassica napus L. with combinations of BAP and NAA, contrasting to our results: these combinations produced few of none buds at all (Table 2). On the other hand, the same authors also obtained positive results with combinations of ZEA and 2,4-D, which is similar to the obtained here, although their calluses were derived from hypocotyls.
Table 2 - Effect of growth regulators on the number of buds per callus of Cecropia glaziovii after 45 days of culture.

\begin{tabular}{ccccc}
\hline \multicolumn{6}{c}{ Growth regulators $\left(\mathrm{mg} \mathrm{L}^{-1}\right)$} & Number of buds per callus \\
\hline BAP & ZEA & $2,4-\mathrm{D}$ & $2 \mathrm{iP}$ & 0.00 \\
\hline 1.0 & 0.0 & 0.0 & 0.0 & 0.00 \\
5.0 & 0.0 & 0.0 & 0.0 & 0.00 \\
10.0 & 0.0 & 0.0 & 0.0 & $6.53 \pm 0.80^{\mathrm{a}}$ \\
0.0 & 0.1 & 0.0 & 0.0 & $5.40 \pm 0.40^{\mathrm{b}}$ \\
0.0 & 0.1 & 1.0 & 0.0 & $5.13 \pm 0.35^{\mathrm{b}}$ \\
0.0 & 0.1 & 3.0 & 0.0 & $4.20 \pm 0.05^{\mathrm{c}}$ \\
0.0 & 0.1 & 5.0 & 0.0 & $2.06 \pm 0.08^{\mathrm{e}}$ \\
0.0 & 0.1 & 10.0 & 0.0 & $1.9 \pm 0.02^{\mathrm{e}}$ \\
0.0 & 0.0 & 5.0 & 1.0 & $1.26 \pm 0.07^{\mathrm{f}}$ \\
0.0 & 0.0 & 10.0 & 1.0 & $2.4 \pm 0.08^{\mathrm{e}}$ \\
1.0 & 0.0 & 1.0 & 0.0 & $2.9 \pm 0.07^{\mathrm{e}}$ \\
5.0 & 0.0 & 3.0 & 0.0 & $4.5 \pm 0.56^{\mathrm{c}}$ \\
1.0 & 0.0 & 5.0 & 0.0 & $0.4 \pm 0.02^{\mathrm{g}}$ \\
1.0 & 0.0 & 10.0 & 0.0 & $0.2 \pm 0.01^{\mathrm{g}}$ \\
5.0 & 0.0 & 10.0 & 0.0 & $0.73 \pm 0.03^{\mathrm{g}}$ \\
5.0 & 0.0 & 5.0 & 0.0 & $3.9 \pm 0.70^{\mathrm{d}}$ \\
0.0 & 0.0 & 5.0 & 0.0 & $4.13 \pm 0.05^{\mathrm{c}}$ \\
0.0 & 0.0 & 10.0 & 0.0 &
\end{tabular}

One-way ANOVA was performed between each growth regulator combinations. Different letters mean significant differences at $5 \%$ (post hoc Tukey test).

After two weeks of culture in MS medium, the established apical and axillary buds and meristems were inoculated in a second MS medium, supplemented with BAP $\left(5.0,10.0 \mathrm{mg} \mathrm{L}^{-1}\right)$ alone or combined with NAA (1.0, $\left.2.0 \mathrm{mg} \mathrm{L}^{-1}\right)$. Vegetative shoot multiplication was observed after 40 - 50 days of culture (Table 3 and Figure 1E). The combination of BAP and NAA seems to be very effective in shoot proliferation: the higher number of buds per explant (15.1 buds per explant) was obtained in a medium supplemented with BAP $10.0 \mathrm{mg} \mathrm{L}^{-1}$ combined with NAA $2.0 \mathrm{mg} \mathrm{L}^{-1}$. Other combinations of growth regulators also induced bud formation, but the number of buds per explant was significantly lower (Table 3 ).

This type of synergism had already been demonstrated in several medicinal plants such as Holostemma annulare (Sudha et al., 1998), Hemidesmus indicus (Sreekumar et al., 2000), Holostemma ada-kodien (Martin, 2002) and Ceropegia candelabrum (Beena et al., 2003). Furthermore, the same results had already been reported in other works on trees (Borkowska, 1989; Amim, 1993). The presence of BAP for bud induction is 
preponderant in the proliferation of shoots of $C$. glaziovii derived from apical or axilary buds. Excellent results were obtained when BAP was used alone in concentrations above $5.0 \mathrm{mg} \mathrm{L}^{-1}$. An alternative combination, which also produced good results, was BAP in concentrations of $10.0 \mathrm{mg} \mathrm{L}^{-1}$ in combination with the auxins IAA and NAA. These results are interesting when compared to the results obtained for bud induction in callus, where BAP was not effective.

Other works aiming the multiplication of trees by vegetative micropropagation demonstrated high levels of success when BAP was applied in lower concentrations than those used here (10 $\mathrm{mg} \mathrm{L}^{-1}$ ) (Radmann et al., 2009); in the same manner, callus formation was also obtained under higher concentrations of BAP (Krikorian, 1995; Schopfer, 1995). In our work, higher BAP concentrations leads to bud multiplication, while lower concentrations leads to callus formation, evidencing specific morphogenesis changes.

\section{Rooting and acclimatization}

The most successful rooting was attained after 30 days by transferring shoots obtained by vegetative multiplication or by indirect organogenesis to MS media supplemented with IAA $\left(0.5\right.$ and $\left.1.0 \mathrm{mg} \mathrm{L}^{-1}\right)$, IBA (3.0 and $\left.5.0 \mathrm{mg} \mathrm{L}^{-1}\right)$. MS basal medium without growth regulators also induced rooting, but in smaller quantity (Table 4 and Figure $1 \mathrm{~F} \mathrm{e} \mathrm{G})$. The plantlets rooted in the treatments IAA 0.5 and $1.0 \mathrm{mg} \mathrm{L}^{-1}$ were successfully established (95\% of survival) under greenhouse conditions after 4 weeks of acclimatization in vermiculite substrate under high humidity
(90 to 100\%). Plants established in the field exhibited morphological characters identical to mother plants.

Table 3 - Effect of growth regulators on the number of buds per explant of Cecropia glaziovii, after 2 weeks of culture on MS primary medium. Results were obtained 40 days after cultivation on $2^{\mathrm{a}}$ medium.

\begin{tabular}{|c|c|c|c|c|c|}
\hline \multicolumn{5}{|c|}{ Growth regulators $\left(\mathrm{mg} \mathrm{L}^{-1}\right)$} & \multirow{2}{*}{$\begin{array}{c}\text { Number of shoots } \\
\text { per explant (apical } \\
\text { or axilary buds) }\end{array}$} \\
\hline BAP & KIN & NAA & IAA & $2 \mathrm{iP}$ & \\
\hline 1.0 & 0.0 & 0.0 & 0.0 & 0.0 & $2.0 \pm 0.03^{\mathrm{gh}}$ \\
\hline 5.0 & 0.0 & 0.0 & 0.0 & 0.0 & $7.5 \pm 1.20^{\mathrm{cd}}$ \\
\hline 10.0 & 0.0 & 0.0 & 0.0 & 0.0 & $9.4 \pm 1.70^{\mathrm{b}}$ \\
\hline 10.0 & 0.0 & 1.0 & 0.0 & 0.0 & $8.7 \pm 0.90^{b c}$ \\
\hline 10.0 & 0.0 & 2.0 & 0.0 & 0.0 & $15.1 \pm 1.40^{\mathrm{a}}$ \\
\hline 10.0 & 0.0 & 5.0 & 0.0 & 0.0 & $7.0 \pm 1.50^{\mathrm{d}}$ \\
\hline 0.0 & 5.0 & 0.0 & 0.0 & 0.0 & $3.2 \pm 0.06^{\mathrm{fg}}$ \\
\hline 0.0 & 10.0 & 0.0 & 0.0 & 0.0 & $0.8 \pm 0.07^{\mathrm{h}}$ \\
\hline 0.0 & 5.0 & 0.0 & 1.0 & 0.0 & $0.9 \pm 0.02^{h}$ \\
\hline 0.0 & 5.0 & 0.0 & 0.0 & 0.1 & $2.6 \pm 0.09^{\mathrm{g}}$ \\
\hline 0.0 & 5.0 & 0.0 & 0.0 & 0.5 & $2.2 \pm 0.08^{\mathrm{gh}}$ \\
\hline 0.0 & 5.0 & 0.0 & 0.0 & 1.0 & $1.0 \pm 0.03^{h}$ \\
\hline 5.0 & 0.0 & 0.0 & 1.0 & 0.0 & $5.1 \pm 0.06^{\mathrm{e}}$ \\
\hline 10.0 & 0.0 & 0.0 & 1.0 & 0.0 & $8.2 \pm 1.00^{b c d}$ \\
\hline 10.0 & 0.0 & 0.0 & 0.0 & 0.1 & $4.2 \pm 0.90^{\mathrm{ef}}$ \\
\hline
\end{tabular}

One-way ANOVA was performed between each growth regulator combinations. Different letters mean significant differences at 5\% (post hoc Tukey test).

Table 4 - Effect of growth regulators on the number of roots per shoot of Cecropia glaziovii after 30 days of culture.

\begin{tabular}{|c|c|c|c|c|c|}
\hline \multicolumn{3}{|c|}{ Growth regulators $\left(\mathrm{mg} \mathrm{L}^{-1}\right)$} & \multirow{2}{*}{$\begin{array}{l}\text { Percentage of root } \\
\text { induction }(\%)\end{array}$} & \multirow{2}{*}{ Number of roots per shoot } & \multirow{2}{*}{ Length of roots $(\mathrm{cm} \pm \mathrm{SE})$} \\
\hline IBA & IAA & NAA & & & \\
\hline 0.0 & 0.0 & 0.0 & 25.0 & $1.70 \pm 0.07^{\text {ef }}$ & $0.80 \pm 0.07^{\mathrm{e}}$ \\
\hline 0.1 & 0.0 & 0.0 & 22.0 & $1.50 \pm 0.05^{\mathrm{f}}$ & $0.60 \pm 0.05^{\mathrm{e}}$ \\
\hline 2.0 & 0.0 & 0.0 & 48.0 & $3.02 \pm 0.11^{\mathrm{c}}$ & $1.60 \pm 0.50^{\mathrm{c}}$ \\
\hline 5.0 & 0.0 & 0.0 & 40.0 & $2.58 \pm 0.40^{\mathrm{d}}$ & $1.50 \pm 0.32^{\mathrm{c}}$ \\
\hline 0.0 & 0.1 & 0.0 & 35.0 & $2.13 \pm 0.09^{\mathrm{e}}$ & $1.40 \pm 0.25^{\mathrm{c}}$ \\
\hline 0.0 & 0.5 & 0.0 & 80.0 & $5.20 \pm 0.05^{b}$ & $2.70 \pm 0.68^{\mathrm{a}}$ \\
\hline 0.0 & 1.0 & 0.0 & 100.0 & $7.95 \pm 0.28^{\mathrm{a}}$ & $2.40 \pm 0.84^{\mathrm{a}}$ \\
\hline 0.0 & 0.0 & 0.1 & 15.0 & $1.20 \pm 0.04^{\mathrm{g}}$ & $0.70 \pm 0.07^{\mathrm{e}}$ \\
\hline 0.0 & 0.0 & 0.5 & 22.0 & $1.40 \pm 0.03^{\mathrm{fg}}$ & $1.00 \pm 0.02^{\mathrm{d}}$ \\
\hline 0.0 & 0.0 & 1.0 & 33.0 & $1.70 \pm 0.05^{\text {ef }}$ & $1.20 \pm 0.03^{\mathrm{d}}$ \\
\hline
\end{tabular}

One-way ANOVA was performed between each growth regulator combinations. Different letters mean significant differences at $5 \%$ (post hoc Tukey test). 


\section{CONCLUSIONS}

Our results reveal that is possible to achieve a large-scale vegetative micropropagation of $C$. glaziovii. This technique provides an alternative way for rapid plant multiplication. Of great interest is the fact that the multiplication from mature plants was achieved without the induction of juvenility, an unusual result in perennials (Greenwood, 1987; Pierik, 1990).

\section{REFERENCES}

BEENA, M.R.; MARTIN, K.P.; KIRTI, P.B.; HARIHARAN, M. Rapíd in vitro propagation of medicinally important Ceropegia candelabrum. Plant Cell Tissue and Organ Culture, Dordrecht, v.72, p.285289, 2003.

BERMÚDEZ, P.P.; BRISA, M.C.; CORNEJO, M.J.; SEGURA, J. In vitro morphogenesis from excised leaf explants of Digitalis obscura L. Plant Cell Reports, v.3, n.1, p.8-9, 1984.

BORKOWSKA, B. Comparative response of sour cherry cultures to different cytokinins. Acta Horticultural, Amsterdam, v.230, p.109-112, 1989.

BURBULIS, N.; KUPRIENE, R.; BLINSTRUBIENE, A. Callus induction and plant regeneration from somatic tissue in spring rapeseed (Brassica napus L.). Biologija, v.54, n.4, p.258-263, 2008.

CASTRO, A.H.F.; PAIVA, R.; ALVARENGA, A.A.de; VITOR, S.M.M. Calogênese e teores de fenóis e taninos totais em barbatimão [Stryphnodendron adstringens (Mart.) Coville]. Ciência e Agrotecnologia, Lavras, v.33, n.2, p.385-390, mar./abr., 2009.

CORRÊA, M.P. As plantas úteis: a Imbaúba, Cecropia pachystachya. [S.1.]: Chácaras e Quintais, 1923.

FONSECA, E.T. Umbaúba. Revista Flora Medicinal, v.11, n.6, p.289-296, 1935.

GREENWOOD, M.S. Rejuvenation of forest trees. Plant Growth Regulation, v.6, n.1/2, p.1-12, 1987.

HIRSCHORN, H.H. Botanical remedies of South and Central America and the Caribbean: an archival analysis part I. Journal of Ethnopharmacology, v.4, p.129-158, 1981.
LAIMER, M.; MACHADO, A.C.; HANZER, V.;

MATTANOVICH, D.; HIMMLER, G; KATINGERM, H.W.D. Regeneration of shoots from leaf discs and stem microcuttings of fruit trees as a tool for transformation. Acta Horticulturale, v.235, p.85-92, 1988.

LIMA, E.C.; PAIVA, R.; NOGUEIRA, R.C.; SOARES, F.P.; EMRICH, E.B.; SILVA, A.A.N. Callus induction in leaf segments of Croton urucurana Baill. Ciência e Agrotecnologia, Lavras, v.32, n.1, p.17-22, 2008.

LIMA-LANDMAN, M.; BORGES, A.; CYSNEIROS. R.; LIMA, T. de; SOUCCAR, C.; LAPA, A. Antihypertensive effect of a standardized aqueous extract of Cecropia glaziovii Sneth in rats: an in vivo approach to the hypotensive mechanism Phytomedicine, v.14, n.5, p.314320, 2007.

LEBLAY, C.; CHEVRESU, E.; RABOIN, L.M.

Adventitious shoot regeneration from "in vitro" leaves of several pear cultivars (Pirus communis L.). Plant Cell Tissue and Organ Culture, Dordrecht, v.25, p.99-105, 1991.

LORENZI, H.; MATOS, F.J.A. Cecropia glaziovii. In: . Plantas medicinais no Brasil: nativas e

exóticas. 2.ed. Nova Odessa: Plantarum, 2008. p.520-521.

MARTIN, K.P. Rapid propagation of Holostemma Adakodien Schult., a rare medicinal plant, through axillary bud multiplication an indirect organogenesis. Plant Cell Reports, v.21, p.112-117, 2002.

MATOS, F.J.A. Plantas medicinais: guia de seleção e emprego de plantas usadas em fitoterapia no nordeste do Brasil. 2.ed. Fortaleza: Imprensa Universitária, 2000. $344 p$.

MONTANARI JUNIOR, I. Aspectos da produção comercial de plantas medicinais nativas. <http:// IWww.cpqba.unicamp.br/plmed/artigos/producao.htm Accessed in: 14 dec. 2008.

MOREIRA, I.F. As plantas que curam. São Paulo: Hemus, 1978. 758p.

MURASHIGE, T. A revised medium for rapid growth and bioassays with tobacco tissue culture. Physiology Plantarum, Copenhagen, v.15, p.473-497, 1962. 
NINAHUAMAN, M.F.M.L.; SOUCCAR, C.; LAPA, A.J.; LIMA-LANDMAN, M.T.R. de. Ace activity during the hypotension produced by standardized aqueous extract of Cecropia glazioui Sneth: a comparative study to captopril effects in rats. Phytomedicine, Stuttgart, v.14, p.321-327, 2007.

PIERIK, R.L.M. Rejuvenation and micropropagation. Newsletter, International Association for Plant Tissue Culture, v.62, p.11-21, 1990.

RADMANN, E.B.; BIANCHI, V.J.; SOUZA, T.M.; FACHINELLO, J.C.; OLIVEIRA, R.P. Influência da composição do meio de cultivo e do tipo de explante na micropropagação do porta-enxerto de Prunus sp. Scientia Agraria, Piracicaba, v.10, n.2, p.95-101, 2009.

SCHOPFER, M. Physiology of hormone action. In: Plant physiology. New York: [s.n.], 1995. p.383408.

SOUCCAR, C.; CYSNEIROS, R.M.; TANAE, M.M.; TORRES, L.M.B.; LIMA-LANDMAN, M.T.R.; LAPA, A.J. Inhibition of gastric acid secretion by a standardized aqueous extract of Cecropia glaziovii Sneth and underlying mechanism. Phytomedicine, Stuttgart, v.15, p.462-469, 2008.

SREEKUMAR, S.; SEENI, S.; PUSHPANGADAN, P. Micropropagation of Hemidesmus indicus for cultivation and production of 2-hydroxy 4-methoxy benzaldehyde. Plant Cell Tissue Organ Culture, Dordrecht, v.62, p.211-218, 2000.

SUDHA, C.G.; KRISHNAN, P.N.; PUSHPANGADAN, P. In vitropropagation of Holostemma annulare (Roxb.) K. Schum., a rare medicinal palnt. In vitro Cell Development Biology Plant, v.33, p.57-63, 1998.

TANAE, M.; LIMA-LANDMAN, M.; LIMA, T. de; SOUCCAR, C.; LAPA, A. Chemical standardization of the aqueous extract of Cecropia glaziovii Sneth endowed with antihypertensive, bronchodilator, antiacid secretion and antidepressant-like activities.

Phytomedicine, v.14, n.5, p.309-313, 2007.

ZAR, J.H. Biostatistical analysis. 4.ed. Englewood Cliffs: Prentice-Hall, 1999. 